\title{
On the possibility of the state without violence
}

Sergei A. Vasiljev

\begin{abstract}
Considering the existing definitions of violence one can point out a lack of terminological unity, which is associated with a lack of objective criteria. As a basis author uses own definition of violence as actions with property without the consent of the owner. Such a definition has an unambiguously defined criterion - the presence or absence of the owner's consent to actions with the object. On the basis of this definition, examples of existing violence from the side of society towards its members are considered. These examples give an idea of what issues in social life are yet violent and how violence can be eliminated. Democracy, the main feature of which is the co-ownership of state property by citizens in equal shares, is considered as an institute that ensures overcoming violence in society. The necessary conditions for ensuring such co-ownership are given. As an example, a state structure is given that provides the necessary features of a democratic state, the main purpose of which is to protect citizens from any encroachment on their property, i.e. protection from violence.
\end{abstract}

Key words: violence, state, democracy, co-ownership, citizenship

A person acquires the concept of violence from an early age. In the ordinary view violence is just a manifestation of strength. A strong person often have an opportunity to impose their will on a weaker one. They used to use is a common expression - the right of the strong one. Many existing definitions of violence mark this very aspect - the application of force to someone or something.

There is no terminological unity and generally accepted understanding in the definition of violence. Since the concept has a long history, it is reflected in many linguistic dictionaries. The Merriam-Webster Dictionary [1] defines violence as the use of physical force so as to injure, abuse, damage, or destroy. Let's note that violence does not always have such a goal. The perpetrator of violence often aims to gain benefits for herself. And this is not always associated with injury, damage and destruction of something or someone.

The Cambridge Dictionary [2] defines violence as actions or words that are intended to hurt people. But again, note that harming others is often not the goal. A rapist is usually anxious to gain benefits for herself and does not care if she is harming another. There are situations when violence is aimed to benefit people rather than to harm, for example some government institutions activity.

The Violence Prevention Alliance [3] defines violence according to the World Report on Violence and Health: "the deliberate use of physical force or power, whether threatening or effective, against oneself, another person or against a group or community that either leads or is likely to result in injury, death, psychological harm, maldevelopment or deprivation. "And again, the use of force by state institutions in relation to citizens and their communities and groups does not always lead or has a high probability of leading to such consequences. For example, a government official can stop and punish a traffic offender. This is also the use of force, which hardly falls under such a definition. Attention is drawn to the "deliberate use of force." Many domestic crimes are committed in a fit of passion, without any intent. Such cases do not fall under this definition either. 
But even the use of force cannot always be considered as violence. This is indicated, in particular, by Garver and Freudenberg [4], citing the example of cases of emergency medical care.

The lack of a uniform understanding of violence is most likely due to the lack of objective criteria. The same actions in relation to the same subject can be considered as violence and as non-violence depending on the circumstances. Violence can be viewed just as an assessment of a phenomenon rather than as objective phenomenon. And since there can be many subjects evaluating the phenomenon, their assessments may differ.

Nevertheless, the subjects evaluating the phenomenon can be rather clearly classified in relation to the belonging of the objects to which the evaluated force is directed. The person whose object of influence is can always give his positive or negative attitude towards the influence. Whereas outside observers can be guided in their assessment by assumptions about whether the impact is good or bad for the person who owns the object of impact. Often assessments are also involved of what effect such an influence has on other subjects, perhaps even not related directly to this impact and this object and this subject. It is obvious that in the absence of clear objective criteria such assessments lead to completely different results. Any international conflict can be cited as an example. The opposing sides are always guided by different assessments of the actions of their own and the other side.

Therefore, in this study, I will be guided only by the assessment of the subject, to whose object the force is directed. Vasiljev [5] defines violence as actions with object without the consent of owner. Any object to which the impact can be directed, as a rule, is someone else's property, and the owner can always evaluate such an impact as acceptable to him or not, which is expressed in his consent or disagreement with such an impact.

Accordingly, I will look for social solutions that make it possible to exclude those influences that fall under the definition of violence above [5]. And as a criterion, I will use not the possible assessments of the recipient of the influence, but their objective expression - the presence or absence of the owner's consent to actions with his object.

\section{Examples of violent practices in society}

At first let's look at examples practiced in modern society that fall under the definition of violence [5]. At that it is necessary to determine what can undoubtedly be considered as a person's property. Vasiljev [6] argued that nature itself defines two initial kinds of human property. First of all this is the human body. It can be in possession and use of the person herself and any actions with human body should be performed only with her consent, otherwise it will be violence. At that I am talking about a person who is recognized as a full member of society.

In addition to the actual actions with the human body without her consent, which are violence according to the definition, there may be threats of such actions. Since the threats of actions are not actions, in this case with the human body, according to the definition, they cannot be violence until implementing threats. Nevertheless below I will consider examples with threats of action if there is a follow-up action as an inevitable consequence of prior threats. The role of such threats in society is fulfilled by the laws of society. By themselves, they are not violence. But if the consent of people is not obtained for actions with property of people, provided for by laws, then such actions will be violence. And since the law presupposes necessary execution, the threat reflected in the law certainly presupposes the subsequent action in pursuance of the law.

Another accessory that people have is natural resources. The only non-violent solution assumes that natural resources should belong to all members of society equally [6]. Accordingly, each member of society can be regarded as an equal co-owner of natural resources. 
People may have or may not have other property, but each of them has or must have these two types from birth. However, a person usually cannot fully own and use them without being recognized as full right member of society. In states this membership usually realized via citizenship.

This issue of citizenship is one of the most important in the state. The age criterion for acquiring citizenship is now generally accepted. It is assumed that by a certain age a person can be aware of the consequences of her actions in relation to both her own and someone else's property, and can bear full responsibility for her actions, but at the same time receiving full rights of a citizen, in particular, in the use and possession of her body. The procedure for acquiring citizenship often does not involve any action on the part of the newly-minted citizen. In some states even a document confirming citizenship is issued few years earlier than upon reaching the appropriate age. On the other hand, the state has laws restricting possession and use of citizens both by their own bodies and by state property, in particular, natural resources. In modern practice neither upon entry into citizenship nor after citizens are usually not asked for any consent to such restrictions. Accordingly if a case provided for by law occurs and government institutions use force to enforce the law the owner's consent has not been obtained for such use of force, and this is violence by definition above. Such a practice exists, for example, in Russia for persons receiving citizenship by birth. It is noteworthy that persons who receive citizenship upon application must take an oath, undertaking to comply with the Constitution and the legislation of the Russian Federation (Federal Law "On Citizenship of the Russian Federation" of May 31, 2002 N 62-FZ, Article 11.1.). Only these persons are explicitly asked for consent to the application of the norms of Russian legislation to them, and only in relation to them the laws of the Russian Federation do not constitute violence, according to the definition of violence adopted above. It is not difficult to see that in order to exclude this type of violence in society; it is enough to ask for such obligations from all persons entering into citizenship.

Some types of violence are already considered as undesirable phenomena and have already been replaced. So compulsory conscription is usually violent. In Russia, for example, conscription is imposed on males from the age of 18 , i.e. simultaneously with the acquisition of citizenship. Young people come under the law the very next day after they come of age. This law imposes restrictions on the use of their bodies, and a part of possession and use of the bodies of young people is transferred to the state, according to the law. When a recruit performs certain actions related to the service, when he is working, shooting, making a march or even just sleeping, his body is being used. And this use and corresponding possession belong to the state. At the same time, the legislation does not imply any request for permission for such possession. By definition, such actions are violent. A number of states have adopted a contractual formation of the armed forces, which implies voluntary relations between the state and citizens, and it is not violence.

But there are also social practices that are considered as democratic gains and, at first glance, it is difficult to discern violence in them. For example, representative legislative power (parliament, duma, senate, etc.). Such institutes are called upon to issue laws that impose restrictions on the actions of people in the state, in particular, with their property. If during elections to such institutes it is not stipulated between citizens and candidates which laws the deputies can adopt and which they cannot, then when the laws are applied in relation to the property of citizens, actions will be taken without their consent, i.e. this is violence.

Another achievement of democracy is local self-government in the form of local (republican, regional, municipal) legislative and/or executive power. If to consider lawmaking, then the reasoning above for the representative legislative branch is applicable to it. However, the situation with the local legislature is more complicated. Any laws are designed to restrict the actions of people with their own and/or someone else's property. And while national laws make such restrictions equal for all members of society, local laws restrict only a part of the members of the community. Moreover, these restrictions must be additional or even contradict the national ones. If, for example, local laws do not complement and do not contradict national laws, then it is not clear why an institute is needed, which only duplicates the state legislative institution. If they contradict and/or supplement, then jurisdictions appear in the 
state in which a part of society lives according to different laws than the rest of society. Even if the part of society that is permanently in this jurisdiction would give its consent to such laws, the rest of the society cannot be asked about their attitude to these laws, since they are outside the framework of this jurisdiction. And if they find themselves in such a jurisdiction, for example, traveling around the country, and local law is applied to them, then actions within the framework of the implementation of the law, consisting in applying any force to people and their property will be violence.

Also local laws, as a rule, regulate actions with natural resources in a certain area. These are, in particular, the issues of land lease for production activities and ordinary life of citizens. According to the above condition resources must belong to all members of society in equal measure. Accordingly, any action with natural resources must be obtained with the consent of all members of society rather than just those who are in the local jurisdiction.

The local executive power can be appointed by the higher leadership or elected by the local population. Paradoxically, the second option is violence. And this is connected with the answer to the question, how many elective positions should be in the executive branch of society? The executive branch is called upon to ensure the observance of laws adopted in society and to engage in economic activities to ensure the same laws. The latter assumes that officials use state property to solve the tasks facing them. It can be shown that nonviolent decision demands that any state property must be owned equally by all members of society. Nevertheless, there are enough natural resources to answer the question posed. Any action with natural resources must be coordinated with all citizens. An elected regional official receives consent for his actions to fulfill his official duties only from a part of citizens. And if a regional elected official disposes of local natural resources, then his actions are performed without the consent of the rest of the society. And these are, in particular, the issues of land lease for residential, commercial and industrial premises and for other needs, without which the work of the local executive authority cannot be imagined.

The sacred cow of modern society is the tax system. In the Tax Code of the Russian Federation, in article 8 , "tax is understood as a mandatory, individually free payment levied from organizations and individuals in the form of alienation of funds belonging to them by right of ownership, economic management or operational management, in order to financially support the activities of the state and (or) municipalities". The obligation of the tax does not imply any consent of the people. Obviously taxes are violent. The tax system, as a way of filling the treasury, came to us from our distant ancestors. In ancient times, in order to raise funds for the treasury it was necessary to demonstrate strength. But in the modern world when market contractual relations can be used to form the revenue side of the budget the demonstration of strength looks more like an atavism. Tellingly, the modern state, as a rule, condemns violent methods, establishing the rights and freedoms of citizens at the level of a national law - the Constitution. And taxes in this case may be in conflict with the declared freedoms of citizens. So in Russia, the Tax Code of the Russian Federation comes into direct conflict with the Constitution of the Russian Federation. According to the article cited above by means of tax money of citizens is forcibly and gratuitously withdrawn (alienated) for state needs. According to the article 130 of the Civil Code of the Russian Federation, money is a (movable) property. But according to part 3 of Article 35 of the Constitution of the Russian Federation, the compulsory alienation of property for state needs can be carried out only on condition of prior and equivalent compensation. But the Tax Code does not imply any compensation, that contradicts to the Constitution.

There are many other examples in modern society that indicate the use of violence against citizens. These are questions of self-determination of nations and nationalities, the so-called private ownership of land, state secrets and much more. In all cases, the criterion for the presence of violence, as already mentioned, is the lack of consent of people to actions with their property. 


\section{The principles of building an ideal state}

An indispensable attribute of every state is its territory. There are no states without territories. The state may or may not have other property, but the territory is the "trademark" of any state. We will, accordingly, consider a state that has a territory and, therefore, natural resources. As mentioned above, resources must be owned equally by all citizens.

It should be noted that democracy, i.e. the power of the people has not yet been realized. Although much is said about democracy, it is not difficult to make sure that the people have never and nowhere been allowed to actually participate in the management and control over the use of state property. The only concession "earned" by the people in the entire history of mankind is free elections of the authorities. This is the only time when those in power depend on the population. After the elections, the authorities are on their own. Making certain decisions, a person is always guided by her own understanding. If this is an employee, then when making decisions, she is also guided by the possible assessment of the employer and the possibility of punishment from the employer for wrong decisions from the point of view of employer. Moreover, the stronger the threat of such punishment and its consequences personally for the person, the more the choice of the decision is based on the possible assessment of the employer. On the contrary, the less the employer's control, the more the employee's decisions correspond to the goals, including the mercantile ones, of the employee herself. If there is virtually no control, then the person is almost always guided by her own opinion, and the employer's opinion is ignored. This is exactly the picture we can see in the power institutes. If the elections indicate that officials are only hired personnel, then the lack of control over them by citizens allows them to ignore the opinion of citizens.

The necessary characteristics of the owner can be obtained by definition of the owner - this is who owns and uses the object. According to [6] the use is the application of physical force to an object, and possession is a potential opportunity to apply this force, which presupposes both knowledge and the possibility of what exactly and where to apply in order to obtain the desired result. For the use it does not matter whether the owner herself applies force to the object or by means something or someone. Accordingly, the first characteristic is the use of one's property by oneself and/or through employees hired for this. Possession assumes that the owner, within the boundaries of his possession, establishes the rules and laws for the use of her property. Accordingly, the second characteristic is the approval of the laws of use. With regard to the state, this implies the establishment of laws for the use of state property. Finally, in order to remain the owner it is necessary to constantly monitor the use of the property, especially if the use is carried out through hired workers, as in the state.

Various ownership options are possible for state property. Not so long ago, just in the Middle Ages, monarchs were considered the owners of states, and more recently dictatorships were practiced. In such state structures the owner of everything in the state was one person. And all the hope of the common people was the kind tsar, the zealous owner, who would not let them die of hunger. Naturally, all these people were not allowed to any control, their opinion was not taken into account even in the management. The very meaning of such management is that if the owner is intelligent she will not tolerate disorder in the "house" and will take care of the prosperity of her "house". In such a system, the monarch (dictator) is considered the only reasonable person, and all the rest, in fact, are unreasonable children whose opinion can be listened to but it does not oblige to anything.

The next step was the transfer of power to a limited circle of people. At first they were called aristocracy, then oligarchy. But the meaning is the same. It was just that government decisions were no longer carried out by a group of persons rather than by one person. They also became the actual owners of state property. And all the other people in the state again were considered insufficiently reasonable to participate in such an important matter. The only difference between this situation and today is that the population is given a purely nominal right to play the elections of the owners once every few years. 
Finally, the last option, which has not yet been implemented anywhere. This is when the rights of the owner in the country are realized for the entire population, and the only criterion for participation in state management is full-right citizenship. I.e. we are talking about the people's state. How, then, should management be organized so that these words are not just a slogan? It is assumed that citizens are equal in rights to state property, i.e. equal co-owners. At that the question arises, what about others, who are potential citizens or who are not citizens? If to consider the existing criteria for infringement of rights, then one can see that this issue has already been practically resolved. This category includes children and persons recognized as incompetent from a medical point of view and persons who have committed illegal acts and are punished for this in court. By the way, the case with the latter is very indicative. After all, we are dealing with crimes (encroachments) against the property rights of other people. I.e. deprivation of the rights of a citizen occurs in the event of her violation of generally recognized property rights. Accordingly, the approval of citizenship should be carried out for persons who are fully aware of these very rights. Co-ownership of state property presupposes decisions on the issues of this property. The necessity of awareness of property rights then looks like the natural requirement for co-owner of state property. For example, adulthood for children should start after passing the maturity exam on the knowledge of relations and property rights rather than from a certain age.

Let's return now to the state property. In addition to territory the state may have other property. For example part of this property can be formed on the basis of contributions from the co-owners themselves. In terms of equality, such property has certain pitfalls. Indeed, if these contributions (for example taxes) are not levied in equal shares from each citizen, then sooner or later such inequality will cause discontent among those who pay more. The question of the equality of citizens does not cause controversy, only if the state property is formed on the basis of the common inheritance of their ancestors received by citizens (mainly territory and natural resources) and income received from the use of this property and possible equal contributions.

Having decided on the owner and, to some extent, on state property, let's try to combine this together. What questions should co-owners decide in order to be the real owners of state property?

1. Adoption of laws by which their society lives and in accordance with which the use of their common property is realized. In the state, as a rule, this is the Constitution. The Constitution stipulates co-owners (citizens) and the state property and all fundamental issues with a change in the status of co-owners (citizens) and the state of property. I.e. it is necessary to answer the following questions. Who can be a citizen? What is the procedure for obtaining citizenship and its deprivation? What is the status of noncitizens, are they so-called "voiceless" co-owners and, accordingly, recipients of public services? If so, what is their share in relation to citizens? What are the general rights and obligations of both citizens and "dependents"? What are the goals and objectives of the society, what is it organized for? What property does it have and what kind of property can it have, based on goals and objectives? (When answering this question, it should be understood that a society can only use the property that belongs to it. It has no right to touch any other's property. Therefore, if such controversial issues arise, it is necessary to determine whether to enter such property in the state register of property, or not to touch upon such issues at all.) What should be the form of using the property? Should there be an administrative apparatus performing these functions, and what should it be, its rights and obligations and the amount of payment? Expenditure items are determined by the goals of society, but must also be reflected explicitly. What are the sources of income for the society? It is also necessary to stipulate measures to protect property from third-party encroachments. Answers to all these questions can be given by the co-owners themselves by voting, the type of which they also determine themselves, or some questions can be instructed to look for an answer to the employees hired for this. In any case, this should also be agreed in advance.

2. Control over the observance of laws. All control functions must be stipulated in the Constitution, as well as who performs them. Citizens can entrust this matter to hired personnel, but it must be remembered that if the citizens themselves, each individually, will not be able to exercise personal 
control, and the laws prescribed in the Constitution will not allow it to be changed in order to provide for such a possibility, then in fact they will cease to be co-owners and will lose their rights to state property. Citizens should be assigned the right to control the use of state property, and without restrictions on the number of citizens. Let it be even one person. If she notices that undesirable actions are being taken with the state property, and therefore with her property, she should have the right to raise the issue of eliminating such actions and punishing the guilty. Nothing gives such a sense of the owner, especially with regard to state property as the possibility of direct control.

There can be a huge variety of answers to the questions posed in paragraph 1 . Each state can respond to them in its own way. It's like a bicycle, for example. It can be large or small, two- or three-wheeled, with different rudders, with different wheels, with a different number of speeds, etc. Much depends on where and how it will be used. The states also differ from one another. Some have more territory, some have less, somewhere have more natural resources, and somewhere less. Different climate, different sources of income, etc.

Now let's give one of the possible options for the structure of an ideal state, of course, not as the only possible one.

\section{An example of the ideal state}

Before building something, one should decide what it is for. So let's start with the goals. Goals can unite, and they can separate people. If goals are not shared by all citizens, there can be confusion and vacillation in society. On the contrary, a single and common goal for all is the guarantee of the unity of society. It is proposed the protection of members of society from any kind of violence as such a goal. There is not and cannot be such a person who would not care about protecting her property if of course she is interested in her existence. Therefore the first goal of the state is to protect co-owners (citizens) from any kind of violence: from nature, individuals and communities, including other states.

1. Protection from violence from the nature involves the following activities.

1.1. Fundamental science as a means of knowing the laws of nature and society.

1.2. Applied science

1.2.1. Prevention and counteraction of various kinds of natural disasters, both terrestrial and cosmic.

1.2.2. Prevention and counteraction of various kinds of diseases, epidemics and pandemics.

1.3. Institute of Education, as a tool for fulfilling the tasks of science.

1.4. Practicing medicine as a means of counteracting various kinds of diseases, epidemics and pandemics.

\subsection{Disaster Resistance Service.}

1.6. Insurance against violence from nature. The occurrence of an insured event can occur both from insufficient knowledge of the laws of nature, and because these very laws do not allow reliable knowledge about the place of time and the subject of the insured event.

2. Protection from violence by individuals and communities within the state involves the following activities.

2.1. Institute of Education as a means of preventing this kind of violence through education. 
2.2. The institution of counteraction (militia, police, court, etc.) as a means of preventing this kind of violence through punishment.

2.3. The institution of fixing contractual relations between subjects within the state.

2.4. Insurance against violence by actors within the state.

3. Protection from violence by communities outside the state involves the following activities.

3.1. Counteraction service (army) as a means of preventing this kind of violence through punishment.

3.2. Institute of International Relations, as a means of establishing and maintaining contractual relations with external communities.

\subsection{Insurance against violence by entities outside the state.}

In addition to the goal of protecting and preserving property the state may have a goal to increase the state property.

Some of these types of activities may not be carried out by the state, leaving it at the mercy of private business. These are the very options mentioned above.

To carry out any kind of activity, the state, like any other community, needs an appropriate tool - an administrative apparatus, through which co-owners (citizens) can use state property.

Let's consider the functions of the administrative apparatus.

1. The legislative power. As mentioned above, the basic law and all amendments to it must be adopted by citizens. The state apparatus can only have an institution that prepares laws for approval by citizens and provides a procedure for adopting laws. The initiative to adopt new laws or amend existing ones should first of all belong to the owner, i.e. citizens. Since there are many citizens, and there can be many proposals at the same time, in order not to drown in legislative activity, there should be a procedure for approbation of proposals. For example, in order to submit a law to a referendum, it must receive the support of a certain quorum of citizens. Modern means of communication, such as the Internet, make it possible to conduct this kind of polls. The institution of the legislature should provide a procedure:

1.1. collecting proposals from citizens;

1.2. making proposals for general discussion;

1.3. collecting information on obtaining a quorum on the proposal;

1.4. submitting a proposal that has received the required quorum to a referendum;

1.5. holding a referendum;

1.6. introducing laws and amendments to the Constitution.

This institution may, of course, have the right to submit its proposals but this seems superfluous. If the employees of the institute are citizens, any of them already has the opportunity to make proposals. Citizens can also delegate to this institution the right to submit its proposals immediately to a referendum bypassing the approbation stage. In this case a subject appears in the state, whose legislative proposals go through a different procedure than for citizens. In the first case, the legislative 
institution has purely executive functions which does not require collegiality and a large number of staff. The second case assumes collegiality, electivity and, accordingly, additional costs. Collegiality stems from the fact that citizens are unlikely to trust one person more legislative rights than they themselves have. And electivity - because for the formation of such a subject it is necessary to obtain the consent of the owner, i.e. citizens. This case can be viewed as a transitional stage to the case with purely executive functions of the legislative institution.

2. The executive power. This function presupposes the use of state property in accordance with the objectives approved by the citizens. The head of the executive branch must be one and must be elected, which, however, is currently the case in many states. The justification for the fact that there should not be other elective positions in the executive branch was given above. The head of the executive branch can build the entire subordinate structure herself, but then she must approve it from the owner, i.e. by referendum, as maintaining the structure requires costs that must be approved by the owner. Also, this structure can be offered to her by the Constitution. Most likely, the second option will be implemented, as it is simpler and less costly. But even in this version, the head of the executive branch should be able to seek the consent of citizens to make any changes to the structure. Its main task is to act within the framework of the goals approved by the Constitution. I.e. goals first, then structure. And if the structure is not optimal to achieve the goals, then the head of the executive branch should be able to raise the issue of changing the structure. This presupposes that the head of the executive branch should have the right to initiate legislation. If she is a citizen, then she already has the right to start from clause 1.1. But getting a quorum on a proposal takes a certain amount of time, which can take a significant part of the term of its hiring.

3. The judicial authority. There have been and are and most likely always will be conflicts over ownership. To resolve them one need a judge who is trusted by the conflicting parties. Therefore, the office of a judge must be elective. All citizens of the state should elect the supreme judge. In a large state with a high frequency of conflicts over property regional and municipal and district judges may be required. For these positions, elections can be held among citizens of the respective locality. At the same time, any of the conflicting parties can demand the examination of the case only in the court in the elections of which it took or should have taken part. Appeals against decisions of local courts can be carried out in the same way as it is done at present, i.e. in higher courts. Litigation costs, at least some of them, should be borne by the party found guilty of property rights infringement.

To carry out any kind of activity, the state needs funds. It was argued above that there should be no taxes in the state. It would seem that these two statements contradict each other. At least quite often the first is cited as an objection to the second statement. Does the state really have no equivalent substitution for taxes? Let us recall how any other entity carries out its activities within the framework of contractual relations. She sells the property she owned or created to others in exchange for their property. Does the state have such property that it can trade? First of all, these are natural resources. The state can sell or rent them for a fee. How to determine the amount of this fee is to be decided by citizens. It can be a certain amount in monetary terms for each resource. Or maybe this fee will be determined through an open auction, who will give more. In general, this is a normal economic activity within the framework of a contractual relationship. What if these funds are not enough to cover expenses? And what does any other entity do if it does not have enough money for expenses? She limits her expenses or increases income through some other contractual activity. In any case, the lack of funds does not give her the right to forcibly take possession of someone else's property. In the state, finally, citizens can additionally chip in to cover these very expenses, as mentioned above.

In addition to the rent for resources the state may have other sources of income. Having such property as the state apparatus the state can receive additional income.

1. Insurance. Currently there are many companies that generate income from this type of activity. The state, in contrast to them, can have a much larger insurance fund that can and should have a positive effect on the confidence of insurers. In addition, insurance companies do not have such kind of security 
forces as police, army, etc. through which the property of insurers, lost as a result of violent actions by individuals and communities, can be returned. I.e. to ensure the insured event, it is not necwssary to spend insurance fund. This means that the cost of providing insurance, respectively, insurance rates from the state may be lower than insurance companies can afford.

2. Issue of national currency. Money is a means of exchanging property within communities. The more property is circulated in the community, the more its equivalent (money) is required. On the example of the dollar, euro and other currencies one can see that money can be in demand not only among citizens of the state in which they are issued, but also in other states. There is a demand for them, and they are also a commodity that can be used to generate income.

3. Income due to the capture of new resources from nature. On the one hand, these may be resources already available to the state, but not developed or insufficiently developed. It can also be resources that did not belong to anyone before. It has already been said above that such resources can also be under the auspices of all mankind. But if humanity comes to an agreement on this, then it will have to stipulate who can use them and how. For example, on the basis of rent to the entire human community. I.e. any of the states, being a part of humanity, will be able to receive income from these resources either in the form of rent or by leasing them from sublease being a leaser.

Of course, other profitable activities are also possible. For example, the provision of property protection services to other states and communities outside the state with the help of the army. However, if we are already considering an ideal state, and in the long term a community of ideal states, the use of the army in interstate conflicts will most likely be the exception rather than the rule and a significant source of income.

And, finally, a few words about control over the activities of the state apparatus.

If a citizen discovered the fact of illegal actions of an official in relation to state or any other property (theft, corruption, etc.), or she believes that the official does not use state property well enough (negligence, idleness, sabotage, etc.), then she should be able to raise the issue of dismissal and/or punishment of an official. If there is an evidence base, then the issue can be resolved in the usual court order. The procedure can be as follows. A citizen submits an application to the appropriate court, which has the authority to consider such an issue. For example, the case of an official of the district level can be tried in the district court, the city - in municipal court, etc. When winning a case in a lawsuit, a citizen must receive a bonus, which is the citizen's motivation to control the actions of officials. The amount of the premium can be determined in the course of the court proceedings as a percentage of the state property saved as a result of the suppression of the unlawful actions of an official, established by law. But the option with statutory amounts of bonuses for each level of officials seems to be more preferable. The losing party must pay the legal costs.

There are, however, cases when the evidence base is difficult to provide, although many people believe that the official is dishonest. If it is an elected official (the President, an official of the legislative power, a judge), the issue of early dismissal should be brought up to those who elect the official. The procedure can be as follows. The citizen submits his proposal to the statutory authority at the place of residence. The proposal is posted on the corresponding website on the Internet to collect a quorum for submitting the issue to the appropriate referendum. Any citizen can support the proposal in the manner prescribed by law. If the required quorum is reached within the time limit established by law, the authority established by law shall organize the holding of the referendum. It is clear that the entire procedure from the presentation of a proposal by a citizen to, possibly, a referendum requires costs from the state. Responsibility for these costs should lie with the losing party. When submitting a proposal for discussion, a citizen should keep in mind that in the event of a loss she will have to pay the costs. Citizens who supported the proposal should keep in mind that if they lose they will share the costs of this stage with initiator. The economic incentive for a citizen to be active should be a premium as in the 
case of a legal proceeding. In case of winning, the citizen and everyone who provided the quorum must receive the prize.

To remove an official appointed by an elected official, for example in the structure of the executive branch, a referendum may not be required. Such an official always has a superior boss who is responsible for his subordinate. In this case, the citizen submits his proposal to this boss. Within the period established by law, the chief gives her answer to the proposal of the citizen. If the answer does not suit the citizen, she can submit the next proposal higher in the hierarchy, in which she notes her claims to both the official and her boss. And so on up to the elected official. If having passed through the authorities from the bottom to the $u$, the issue is not resolved by the head of the executive branch a citizen can initiate a referendum. Thus each official is responsible for her subordinates. And any citizen is financially motivated to exercise control over the use of state property.

And finally, the activities of the state can be unprofitable or profitable. In the first case, citizens must cover the lack of expenditure from their own pockets. If the activity of the state is organized in such a way that it makes a profit, then profit should be paid to all citizens and potential citizens. Currently, many states spend significant funds on social policy. And properly organized activities of the state can bring citizens such profits, which to a large extent, if not completely will cover many social costs, such as the minimum living wage, medical care, child support, etc. By the way, children, as potential co-owners, will simply have their share of the profits from government activities.

\section{Literature}

1. The Merriam-Webster Dictionary, https://www.merriam-webster.com/dictionary/violence. Last visited at 06.14.2021.

2. The Cambridge Dictionary, https://dictionary.cambridge.org/dictionary/english/violence. Last visited at 06.14.2021.

3. The Violence Prevention Alliance (VPA), https://www.who.int/violenceprevention/approach/definition/en/. Last visited at 06.14.2021.

4. Newton Garver \& Edgar Z. Friedenberg. WHAT VIOLENCE IS. Nation, June 24, 1968, pp. 817-822.

5. Sergei A. Vasiljev. The Newton's Third Law in Social Relations// History, political science, sociology, philosophy: theoretical and practical aspects. XXIV-XXV international conf. № 910(17). - Novosibirsk: SibAC, 2019. - P. 46-54. Also available at SSRN: https://ssrn.com/abstract=2867829 or http://dx.doi.org/10.2139/ssrn.2867829

6. Sergei A. Vasiljev. Physical Approach to Possession and Use // The philosophy of social communications. N1(54), 2021, pp. 40-49. (In Russian). Also available at SSRN: https://ssrn.com/abstract=3586495 or http://dx.doi.org/10.2139/ssrn.3586495 